\title{
Apple Fruit Growth and Maturity are Affected by Early Season Temperatures
}

\author{
I.J. Warrington, T.A. Fulton, E.A. Halligan, and H.N. de Silva \\ The Horticulture and Food Research Institute of New Zealand Ltd., Private Bag 11030, Palmerston North, \\ New Zealand
}

Additional INDEX words. Malus sylvestris var. domestica, fruit expansion, fruit weight, cell division, soluble solids concentration, fruit firmness, background color index

\begin{abstract}
Container-grown 'Delicious', ‘Golden Delicious', 'Braeburn', 'Fuji’ and 'Royal Gala' apple [Malus sylvestris (L.) Mill. var.domestica (Borkh.) Mansf.] trees, on Malling 9 (M.9) rootstock, were subjected to a range of different maximum/ minimum air temperature regimes for up to 80 days after full bloom (DAFB) in controlled environments to investigate the effects of temperature on fruit expansion, final fruit weight, and fruit maturation. Fruit expansion rates were highly responsive to temperature with those at a mean of $20^{\circ} \mathrm{C}$ being $\approx 10$ times greater than those at a mean of $6^{\circ} \mathrm{C}$. All cultivars exhibited the same general response although 'Braeburn' consistently showed higher expansion rates at all temperatures compared with lowest rates for 'Golden Delicious' and intermediate rates for both 'Delicious' and 'Fuji'. The duration of cell division, assessed indirectly by measuring expansion rate, appeared to be inversely related to mean temperature (i.e., prolonged under cooler conditions). Subsequently, fruit on trees from the coolest controlled temperature treatment showed greater expansion rates when transferred to the field and smaller differences in fruit size at harvest than would have been expected from the measured expansion rates under the cool treatment. Nonetheless, mean fruit weight from warm postbloom treatments was up to four times greater at harvest maturity than that from cool temperature treatments. Postbloom temperature also markedly affected fruit maturation. Fruit from warm postbloom temperature conditions had a higher soluble solids concentration, more yellow background color, lower flesh firmness, and greater starch hydrolysis than fruit from cooler temperatures.
\end{abstract}

Crop load and the genetic biological carrying capacity (sourcesink relationships) determine the potential for fruit size development in apple (Malus sylvestris var. domestica). However, the environment within which the fruit grow attenuates this potential and the impacts of factors such as light and temperature must be understood if economic returns from commercial apple orchards are to be maximized.

A number of studies have shown a strong positive correlation between temperatures immediately following bloom in the field and fruit size at harvest (Abbott and Bull, 1973; Beattie and Folley, 1978; Blanpied and O'Kennedy, 1967; Green, 1981; Jackson and Hamer, 1980; Jackson et al., 1983; Lakso et al., 1995). In a few instances, attempts have been made to grow trees under modified environments in order to study these relationships in more detail. In earlier studies, temperature treatments imposed on branches during the night were able to influence fruit growth rates (Tukey, 1956, 1959). Controlled environment rooms have also been used to expose whole trees to different temperature conditions. For example, Ford (1979) exposed small trees to two contrasting temperature regimes for 3 weeks postbloom and a strong impact of temperature on mean fruit diameter was demonstrated. In a more recent study, Tromp (1997) showed that postbloom temperature treatments markedly affected fruit maturation but had only a small impact on fruit weight at harvest. Nonetheless, these studies were very limited and quantitative information on these responses is not available which would allow the impacts of seasonal temperature variations on final fruit size or maturity to be predicted.

The impacts of temperature on apple fruit growth are further

Received for publication 15 June 1998. Accepted for publication 3 May. We thank the staff of the National Climate Laboratory, HortResearch, Palmerston North, New Zealand, for maintaining the controlled environment rooms used in this study. This project was funded as part of a contract with the New Zealand Foundation for Research, Science, and Technology. The cost of publishing this paper was defrayed in part by the payment of page charges. Under postal regulations, this paper therefore must be hereby marked advertisement solely to indicate this fact. complicated by development phase. The apple fruit grows in two distinct phases: an early exponential phase of cell division that typically lasts for $\approx 35$ to $45 \mathrm{~d}$ after anthesis, followed by a cell expansion phase for the remainder of the season until commercial maturity (Blanpied and Wilde, 1968; Bollard, 1970; Pratt, 1988). This overall pattern of fruit growth (weight basis) has been described using expolinear (Lakso et al., 1995), Gompertz, and logistic (Gandar et al., 1996) models. Earlier attempts to model the seasonal growth curve with two linear sections approximating the phases of cell division and cell expansion were less successful but two distinct phases were evident (Schechter et al., 1993a, 1993b).

In addition to the general relationships that have been determined between temperature and fruit growth, others have shown that the timing of exposure to temperature is significant. Hence the weight or diameter of apples at $\approx 40 \mathrm{~d}$ after full bloom (DAFB) has been shown to be related to final fruit diameter (Batjer et al., 1960; Bergh, 1990; Forshey, 1976). The implication, therefore, is that the early exponential cell division phase is considerably more responsive to temperature than the following predominantly cell expansion phase. This assumption, however, remains to be demonstrated experimentally. Therefore, the following studies were conducted to quantify the effects of air temperature on the early growth of apple fruit both during the initial cell division phase and subsequently during the early cell expansion phase that follows the cell division phase (i.e., for up to $80 \mathrm{~d}$ whereas the length of fruit development is $\approx 140$ to 180 $\mathrm{d}$ in total).

\section{Materials and Methods}

Cultural. Apple trees of 'Braeburn', 'Delicious' strain Harrold Red, 'Golden Delicious', 'Royal Gala' and 'Fuji', grafted on M.9 rootstock and grown in pots, were studied in a series of controlled environment (CE) experiments conducted in the National Climate Laboratory, HortResearch, Palmerston North, New Zealand (DSIR, 1981), over a period of several years. The trees were grown in a fertilized medium of 1 sand : 1 pumice : 1 peat (by volume), in 30 
$\mathrm{L}$ containers. They were top-dressed twice yearly with $75 \mathrm{~g} /$ container each of Osmocote, $14 \mathrm{~N}-6.1 \mathrm{P}-11.6 \mathrm{~K}$ (3 to 4 months release) and Osmocote, $18 \mathrm{~N}-2.6 \mathrm{P}-10 \mathrm{~K}$ ( 9 to 10 months release) fertilizers (Grace Sierra, Heerlen, The Netherlands) and irrigated to ensure no moisture deficits occurred. The trees, which were 1.5 to $2.0 \mathrm{~m}$ tall, were trained to have a dominant central leader and one basal whorl of three to four scaffold branches.

Over the duration of the experiment, a large population of trees was maintained in an outdoor site surrounded by windbreaks. For each experiment, trees were randomly selected from this population. During bloom, all trees were pollinated by hand with 'Granny Smith' apple pollen and the pollination date (0 DAFB) was recorded. Clusters were thinned to two pollinated flowers and subsequently to 20 to 25 clusters with the same bloom date $( \pm 2 \mathrm{DAFB})$, on each tree. After the controlled environment phase of each experiment, trees were returned to the field.

ENVIRONMENTAL CONDITIONS. The experiments were designed to investigate the effect of different air temperature regimes, imposed at various physiological stages, i.e. days after full bloom (DAFB), on apple fruit development both during exposure to various treatments and subsequently during development through to final harvest. Temperatures for each experiment are reported as maximum/minimum. A maximum/minimum water vapor pressure deficit of $0.4 / 0.2 \mathrm{kPa}$ was maintained in each treatment to standardize evaporative demand, irrespective of temperature. Temperature treatments were programmed to follow a sine wave pattern over each $24 \mathrm{~h}$ period with the maximum occurring $6 \mathrm{~h}$ into the main photosynthetic light period and the minimum, $6 \mathrm{~h}$ into the dark period. The photoperiod was $12 \mathrm{~h}$ in Expt. 1 but in Expts. 2, 3, and 4, an extension of $1 \mathrm{~h}$ of supplementary low photoperiodic lighting was added at the end of the main light period. Lighting, which was either on or off (not ramped), was supplied by four, $1 \mathrm{~kW}$ Sylvania 'Metal-arc' lamps and four, 1 $\mathrm{kW}$ tungsten iodide lamps (Warrington et al., 1978) and resulted in a mean photosynthetic photon flux $(P P F)$ at mid plant height of $715,694,693$, and $687 \mu \mathrm{mol} \cdot \mathrm{m}^{-2} \cdot \mathrm{s}^{-1}$ for Expts. 1, 2, 3, and 4, respectively. Carbon dioxide concentration was maintained at $340 \mu \mathrm{L} \cdot \mathrm{L}^{-1}$ air within all temperature treatments. Water and balanced mineral nutrition (modified Hoagland's A solution; Brooking, 1976) were supplied via an automated microtube delivery system to the trees as required during the various controlled environment treatments.

EXPERIMENT 1: THE IMPACT OF TEMPERATURE ON EARLY APPLE FRUIT GROWTH (OCTOBER 1993 TO APRIL 1994). Three-year-old trees of 'Golden Delicious', 'Delicious' and 'Fuji' were transferred to each of the temperature treatments at 10 DAFB (0 DAFB was 25 Oct.), using five or six trees of each cultivar in each treatment. The temperature regimes were 13/3, 16/6, 19/9, and $22 / 12^{\circ} \mathrm{C}$, with a treatment period from 10 until 40 DAFB. These temperature treatments, and the others used throughout the study, were chosen to represent the range of mean temperatures and maximum/minimum temperature differentials that occur during bloom and early fruit growth at commercial production sites in New Zealand (see, for example, Austin et al., 1999).

EXPERIMENT 2: THE IMPACT OF TEMPERATURE DURING EARLY CELL DIVISION AND SUBSEQUENT CELL ENLARGEMENT ON APPLE FRUIT GROWTH (OCTOBER 1994 TO APRIL 1995). Temperature treatments of $9 / 3,13 / 3,19 / 9$, and $25 / 15^{\circ} \mathrm{C}$ were imposed over three development periods. In addition to a 10 to $40 \mathrm{DAFB}$ period, treatments were also imposed for 10 to 80 and 40 to 80 DAFB to allow individual effects of temperature on early fruit development (predominantly cell division) and later fruit development (predominantly cell expansion) to be determined. The 13/3 and $19 / 9{ }^{\circ} \mathrm{C}$ temperature treatments imposed in the 10 to $40 \mathrm{DAFB}$ period provided some replication of the previous year's treatments. 'Golden Delicious', 'Delicious' and 'Fuji' trees (4-yearold) were selected, with the addition of 3-year-old 'Braeburn' trees. Where possible, each treatment combination included three trees per cultivar. However, limited space and the limited number of trees of some cultivars led to the following exceptions: for 'Delicious', two trees were used in the 10 to 80 DAFB period; 'Golden Delicious' and 'Fuji' were restricted to only the 10 to 40 DAFB period and within that, 'Fuji' was subjected only to $13 / 3$ and $19 / 9{ }^{\circ} \mathrm{C}$ temperature regimes.

EXPERIMENT 3: THE EFFECT OF MAXIMUM/MINIMUM TEMPERATURE DIFFERENTIAL ON FRUIT DEVELOPMENT (OCTOBER 1995 TO MAY 1996). Four-year-old 'Braeburn' trees were subjected to temperature regimes of $16 / 6,19 / 3{ }^{\circ} \mathrm{C}$ (each with a mean temperature of $11^{\circ} \mathrm{C}$ but with differentials of 10 and $16^{\circ} \mathrm{C}$, respectively) and $22 / 12$ and $25 / 9{ }^{\circ} \mathrm{C}$ (mean of $17^{\circ} \mathrm{C}$ and differentials of 10 and $16^{\circ} \mathrm{C}$ ). The trees were placed in these temperature treatments for periods of 1 to 10,1 to 63 or 10 to 63 DAFB.

EXPERIMENT 4: THE EFFECT OF CONTRASTING TEMPERATURES ON EARLY APPLE FRUIT GROWTH-REPLICATION TREATMENTS (OCTOBER 1996 TO MAY 1997). Sixteen trees of 'Braeburn' and eight trees of both 'Fuji' and 'Royal Gala', were subjected to temperature regimes of either $13 / 3$ or $22 / 12{ }^{\circ} \mathrm{C}$ from 1 to 40 DAFB. Each of the two temperature regimes were replicated in two different controlled environment rooms.

Data collection. Measurements of fruit diameter were nondestructively recorded using hand-held vernier calipers, on 10 representative fruit per tree twice weekly while in the $\mathrm{CE}$ treatments. Each tree carried $\approx 30$ fruit and following transfer of trees to the field, fruit were thinned to 20 per tree and measurements were continued on the same 10 fruit but on a biweekly basis. If a fruit that was being measured abscised or became damaged it was, where possible, replaced with another of the same size from the 10 additional fruit on the tree.

The final harvest for each experiment was carried out when apples from the earliest maturing treatment were considered to be at commercial harvest stage (as assessed primarily by background color development). All treatments for the same cultivar were harvested on the same date, except for those in Expt. 4. In this experiment, all the 'mature' fruit from the most advanced treatment and half of the 'immature' fruit from the other treatments were harvested on the same date. Remaining fruit were harvested as they ultimately reached the same background color index. The harvest dates for Expt. 1 were 15 Mar. for 'Golden Delicious' (141 DAFB), 22 Mar. for 'Delicious' (148 DAFB) and 12 Apr. for 'Fuji' (169 DAFB). For Expt. 2 the harvest dates were 13 Mar. for 'Delicious' (142 DAFB), 21 Mar. for 'Golden Delicious' (146 DAFB), 27 Mar. for 'Braeburn' (158 DAFB), and 18 Apr. for 'Fuji' (174 DAFB). For Expt. 3 the harvest dates were 10 Apr. (175 DAFB). In Expt. 4, 'Braeburn' was harvested from 18 Mar. to 14 Apr. (173 to 201 DAFB), 'Fuji' from 9 Apr. to 28 Apr. (151 to $170 \mathrm{DAFB})$, and 'Royal Gala' from 13 Mar. to 24 Mar. (130 to 141 DAFB).

At harvest, fruit diameter, fruit length, and fresh weight were measured on the 20 fruit per tree. Indices of physiological maturity were quantified as follows: skin background color using industry fruit maturity color swatches; flesh firmness, using an Effigi, R. Bryce penetrometer (Effigi, 48011 Alfonsine, Italy) on peeled equatorial positions on both the exposed and shaded sides of the fruit; starch pattern index determined from the starch- 
Table 1. Mean expansion rates [10-40 d after full bloom (DAFB)]), and mean harvest weight of fruit on trees subjected to four controlled temperature regimes from 10 to 40 DAFB. [Expt. 1 (1993-94)].

\begin{tabular}{|c|c|c|c|c|c|}
\hline \multirow[b]{2}{*}{ Cultivar } & \multicolumn{4}{|c|}{$\operatorname{Max} / \min$ temp $\left({ }^{\circ} \mathrm{C}\right)$} & \multirow[b]{2}{*}{ SE ratio ${ }^{z}$} \\
\hline & $13 / 3$ & $16 / 6$ & $19 / 9$ & $22 / 12$ & \\
\hline & \multicolumn{5}{|c|}{ Fruit expansion rate $\left(\mathrm{mm} \cdot \mathrm{d}^{-1}\right)$} \\
\hline 'Delicious' & $0.25 \mathrm{~d}^{\mathrm{y}}$ & $0.44 \mathrm{c}$ & $0.71 \mathrm{~b}$ & $0.91 \mathrm{a}$ & $1.04^{* * * *}$ \\
\hline 'Golden Delicious' & $0.21 \mathrm{~d}$ & $0.42 \mathrm{c}$ & $0.63 \mathrm{~b}$ & $0.82 \mathrm{a}$ & $1.03^{* * * *}$ \\
\hline \multirow[t]{2}{*}{ 'Fuji' } & $0.25 \mathrm{~d}$ & $0.52 \mathrm{c}$ & $0.77 \mathrm{~b}$ & $0.94 \mathrm{a}$ & $1.03^{* * * *}$ \\
\hline & \multicolumn{4}{|c|}{ Harvest fruit wt $(\mathrm{g})^{\mathrm{x}}$} & $\operatorname{LSD}_{(0.05)}$ \\
\hline 'Delicious' & $153 \mathrm{~b}$ & $157 \mathrm{~b}$ & $224 \mathrm{a}$ & $219 a$ & $51^{* * *}$ \\
\hline 'Golden Delicious' & $112 \mathrm{~b}$ & $132 \mathrm{~b}$ & $171 \mathrm{a}$ & $186 \mathrm{a}$ & $29^{* *}$ \\
\hline 'Fuji' & 178 & 192 & 194 & 199 & $36^{\mathrm{NS}}$ \\
\hline
\end{tabular}

${ }^{\mathrm{z}}$ Multiply or divide the estimate of expansion rate by the SE ratio to obtain the lower and upper bounds of unit standard error about the mean.

'Mean separation within rows by Fisher's protected LSD, $P \leq 0.05$.

${ }^{\mathrm{x}}$ All fruit harvested when those at $22 / 12^{\circ} \mathrm{C}$ had reached commercial maturity.

Ns, $* *, * * *$ Nonsignificant or significant at $P \leq 0.01$, or 0.001 , respectively.

iodine reaction where each fruit cut transversely in half was assessed on a scale of 1 to 6 , where $1=$ minimal starch hydrolysis and $6=$ complete starch hydrolysis; and soluble solids concentration (SSC) was measured with an Atago refractometer (Atago Co., Ltd., Itabashi-ku, Tokyo, Japan) using juice obtained during flesh firmness determination. The number and fresh weight of seeds in each fruit were also recorded.

STATISTICAL ANalySES. All fruit diameter measurements within a tree were averaged to provide tree means. For each time period (10 to 40 or 40 to $80 \mathrm{DAFB}$ ) the fruit diameter expansion rates (millimeters per day) were calculated at the individual tree level based on tree mean estimates. Here, the rate of change in size is expressed as fruit diameter expansion rather than volume expansion. Expansion rates were logarithmic transformed and analyzed using a general linear model (GLM) to compare temperature effects on fruit expansion and growth. Standard errors when back-trans- formed provided estimates of standard error ratios for the treatment means presented on the original scale. A treatment mean when divided and multiplied by the standard error ratio provides the lower and upper limits respectively, of a unit standard error about the mean. Separate analyses were carried out for each cultivar $x$ temperature-time period combination. It is noted that although de Silva et al. (1997) have developed a diameter-weight calibration equation for 'Royal Gala' the applicability of this equation to other cultivars has not been tested.

When initial sizes are different, diameter expansion rates will not provide a valid comparison of fruit volumetric growth rates. Particularly, in such instances comparisons were made between approximated volumetric growth rates, assuming the surface area of fruit was proportional to the squared value of the diameter. The overall fruit diameter expansion profiles under different temperature treatments were described graphically by fitting B-splines to the data.

Table 2. Estimates of mean fruit expansion rate $\left(\mathrm{mm} \cdot \mathrm{d}^{-1}\right)$ of fruit on apple trees subjected to four temperature regimes at three growth phases under controlled environment conditions. [Expt. 2 (1994-95)].

\begin{tabular}{|c|c|c|c|c|c|c|}
\hline \multirow[b]{3}{*}{ Cultivar } & \multirow{3}{*}{$\begin{array}{l}\text { Time period } \\
\left(\mathrm{DAFB}^{\mathrm{y}}\right)\end{array}$} & \multicolumn{4}{|c|}{ Mean fruit expansion rate $\left(\mathrm{mm} \cdot \mathrm{d}^{-1}\right)$} & \multirow[b]{3}{*}{ SE ratio } \\
\hline & & \multicolumn{4}{|c|}{$\operatorname{Max} / \min$ temp $\left({ }^{\circ} \mathrm{C}\right)$} & \\
\hline & & $9 / 3$ & $13 / 3$ & $19 / 9$ & $25 / 15$ & \\
\hline & Treatment from 10 to 40 DAFB & & & & & \\
\hline \multirow[t]{2}{*}{ 'Golden Delicious' } & 10 to 40 & $0.10 b^{x}$ & $0.11 \mathrm{~b}$ & $0.58 \mathrm{a}$ & $0.87 \mathrm{a}$ & $1.20^{* * * *}$ \\
\hline & 40 to 80 (outdoors) & $0.87 \mathrm{a}$ & $0.88 \mathrm{a}$ & $0.71 \mathrm{~b}$ & $0.72 \mathrm{~b}$ & $1.03^{* *}$ \\
\hline \multirow[t]{3}{*}{ 'Fuji' } & 10 to 40 & --- & $0.22 \mathrm{~b}$ & $0.62 \mathrm{a}$ & --- & $1.03^{* *}$ \\
\hline & 40 to 80 (outdoors) & --- & $0.89 \mathrm{a}$ & $0.60 \mathrm{~b}$ & --- & $1.03^{* * *}$ \\
\hline & Treatment from 10 to 40 or 10 to 80 DAFB & & & & & \\
\hline \multirow[t]{3}{*}{ 'Braeburn' } & 10 to $40^{\mathrm{w}}$ & $0.24 \mathrm{~d}$ & $0.42 \mathrm{c}$ & $0.79 \mathrm{~b}$ & $0.98 \mathrm{a}$ & $1.04^{* * * *}$ \\
\hline & 40 to $80^{v}$ & $0.35 \mathrm{~b}$ & $0.48 \mathrm{a}$ & $0.56 \mathrm{a}$ & $0.53 \mathrm{a}$ & $1.08^{* * *}$ \\
\hline & 40 to 80 (outdoors) & $0.80 \mathrm{a}$ & $0.79 \mathrm{a}$ & $0.62 \mathrm{~b}$ & $0.46 \mathrm{c}$ & $1.05^{* *}$ \\
\hline \multirow[t]{4}{*}{ 'Delicious' } & 10 to $40^{\mathrm{w}}$ & $0.12 \mathrm{~d}$ & $0.24 \mathrm{c}$ & $0.61 \mathrm{~b}$ & $0.98 \mathrm{a}$ & $1.07^{* * *}$ \\
\hline & 40 to $80^{v}$ & $0.19 \mathrm{c}$ & $0.36 \mathrm{~b}$ & $0.51 \mathrm{a}$ & $0.56 \mathrm{a}$ & $1.09^{* *}$ \\
\hline & 40 to 80 (outdoors) & $0.84 \mathrm{a}$ & $0.76 \mathrm{ab}$ & $0.60 \mathrm{c}$ & $0.69 \mathrm{bc}$ & $1.06^{*}$ \\
\hline & Treatment from 40 to 80 DAFB & & & & & \\
\hline 'Braeburn' & 40 to 80 & $0.30 \mathrm{c}$ & $0.38 \mathrm{bc}$ & $0.47 \mathrm{ab}$ & $0.52 \mathrm{a}$ & $1.11^{*}$ \\
\hline 'Delicious' & 40 to 80 & $0.25 \mathrm{~b}$ & $0.29 \mathrm{~b}$ & $0.46 \mathrm{a}$ & $0.59 \mathrm{a}$ & $1.11^{* *}$ \\
\hline
\end{tabular}


Table 3. Mean harvest weight of fruit on trees subjected to four controlled temperature regimes at three different fruit growth phases. [Expt. 2 $(1994-95)]^{\mathrm{z}}$.

\begin{tabular}{|c|c|c|c|c|c|c|}
\hline \multirow[b]{3}{*}{ Cultivar } & \multirow[b]{3}{*}{ Time period $\left(\mathrm{DAFB}^{\mathrm{y}}\right)$} & \multicolumn{4}{|c|}{ Mean fruit wt (g) } & \multirow[b]{3}{*}{$\operatorname{LSD}_{(0.05}$} \\
\hline & & \multicolumn{4}{|c|}{$\operatorname{Max} / \min$ temp $\left({ }^{\circ} \mathrm{C}\right)$} & \\
\hline & & $9 / 3$ & $13 / 3$ & $19 / 9$ & $25 / 15$ & \\
\hline \multirow{3}{*}{ 'Braeburn' } & $10-40$ & 183 & 226 & 224 & 185 & $53^{\mathrm{NS}}$ \\
\hline & $10-80$ & $169 b^{x}$ & $174 \mathrm{~b}$ & $271 \mathrm{a}$ & $203 \mathrm{a}$ & $65^{*}$ \\
\hline & $40-80$ & 162 & 224 & 197 & 225 & $53^{\mathrm{NS}}$ \\
\hline \multirow[t]{3}{*}{ 'Delicious' } & $10-40$ & $132 \mathrm{~b}$ & $135 \mathrm{~b}$ & $137 \mathrm{~b}$ & $269 a$ & $87^{*}$ \\
\hline & $10-80$ & $60 \mathrm{~b}$ & $84 \mathrm{~b}$ & $148 \mathrm{~b}$ & $250 \mathrm{a}$ & $111^{*}$ \\
\hline & $40-80$ & 115 & 148 & 147 & 129 & $46^{\mathrm{NS}}$ \\
\hline
\end{tabular}

${ }^{\mathrm{z}} \mathrm{All}$ fruit harvested when those at $25 / 15^{\circ} \mathrm{C}$ had reached commercial harvest maturity.

${ }^{\mathrm{y}} \mathrm{DAFB}=$ days after full bloom.

${ }^{x}$ Mean separation within rows by Fisher's protected LSD, $P \leq 0.05$.

ns ${ }^{*}$ Nonsignificant or significant at $P \leq 0.05$.

\section{Results}

EXPERIMENT 1. Temperature treatments imposed from 10 to 40 DAFB significantly affected mean fruit expansion rate over the same period in all three cultivars, with rates at $22 / 12^{\circ} \mathrm{C}$ being almost 4-fold greater than those at $13 / 3^{\circ} \mathrm{C}$ (Table 1). Cultivars did not differ significantly in their temperature response. At 40 DAFB trees were placed in the sheltered outdoor site until harvest. The harvest fruit weights (Table 1), measured on a common harvest date depending on the cultivar, did not differ among treatment temperatures as much as might have been expected from the early fruit expansion rates. For 'Delicious', for example, there was no significant difference in mean harvest fruit weight between $13 / 3$ and $16 / 6^{\circ} \mathrm{C}$. Implicitly, therefore, fruit subjected previously to $13 / 3^{\circ} \mathrm{C}$ had a greater average expansion rate and a greater volumetric growth rate over the period between 40 DAFB until harvest than fruit previously grown at $16 / 6{ }^{\circ} \mathrm{C}$. On average, 'Delicious' and 'Golden Delicious' had almost $75 \mathrm{~g}$ larger fruit at 22/12 compared with that from the $13 / 3^{\circ} \mathrm{C}$ treatment whereas for 'Fuji' the differences were markedly less and were not significant.

EXPERIMENT 2. Temperature imposed from 10 to 40 DAFB in 1994-95 significantly affected mean fruit expansion rate for both 'Delicious' and 'Golden Delicious', a wider range in mean fruit expansion rates being expressed for the wider range of temperature treatments compared with those imposed in the previous year (Table 2). For 'Braeburn', there was a 4-fold difference in mean expansion rate (10 to $40 \mathrm{DAFB})$ between the extreme temperatures, while the range of the expansion rate response was even greater for 'Delicious' and 'Golden Delicious'. In both the $9 / 3$ and $13 / 3{ }^{\circ} \mathrm{C}$ regimes where temperatures had been imposed from 10 to $40 \mathrm{DAFB}$, there was a marked increase in mean fruit expansion rate once the trees were placed in the sheltered outdoor site [40 to 80 DAFB (outdoors)]; (Table 2). In fact, prolonged exposure to cool temperatures continued to restrict fruit expansion rates. For example, with 'Delicious', fruit on trees that continued to be exposed to $9 / 3{ }^{\circ} \mathrm{C}$ over the entire 10 to $80 \mathrm{DAFB}$ period had a mean expansion rate of 0.19 $\mathrm{mm} \cdot \mathrm{d}^{-1}$ during 40 to $80 \mathrm{DAFB}$, compared with $0.84 \mathrm{~mm} \cdot \mathrm{d}^{-1}$ over the same period for trees that were transferred to the outdoor site. A similar result was observed in the $13 / 3{ }^{\circ} \mathrm{C}$ treatment and there was a consistency in the response for both 'Delicious' and 'Braeburn'.

Prolonged exposure to cool temperature conditions from 10 to 80 DAFB also had a marked effect on final fruit weight of 'Delicious' with an approximate $50 \%$ reduction at $9 / 3{ }^{\circ} \mathrm{C}$ (compared to fruit exposed over the 10 to 40 DAFB period), which was not compensated for by higher growth rates under subsequent warmer outdoor temperatures (Table 3). This effect was also evident with 'Braeburn' but was much smaller in magnitude.

Temperature induced differences in mean fruit expansion rates among treatments were much smaller in fruit exposed to different treatments from 40 to 80 DAFB than they were for fruit exposed from 10 to 40 DAFB. For 'Delicious' the difference in mean fruit expansion rate between $9 / 3{ }^{\circ} \mathrm{C}$ and $25 / 15^{\circ} \mathrm{C}$ was $\approx 2$-fold. The comparative difference with 'Braeburn' was smaller (Table 2).

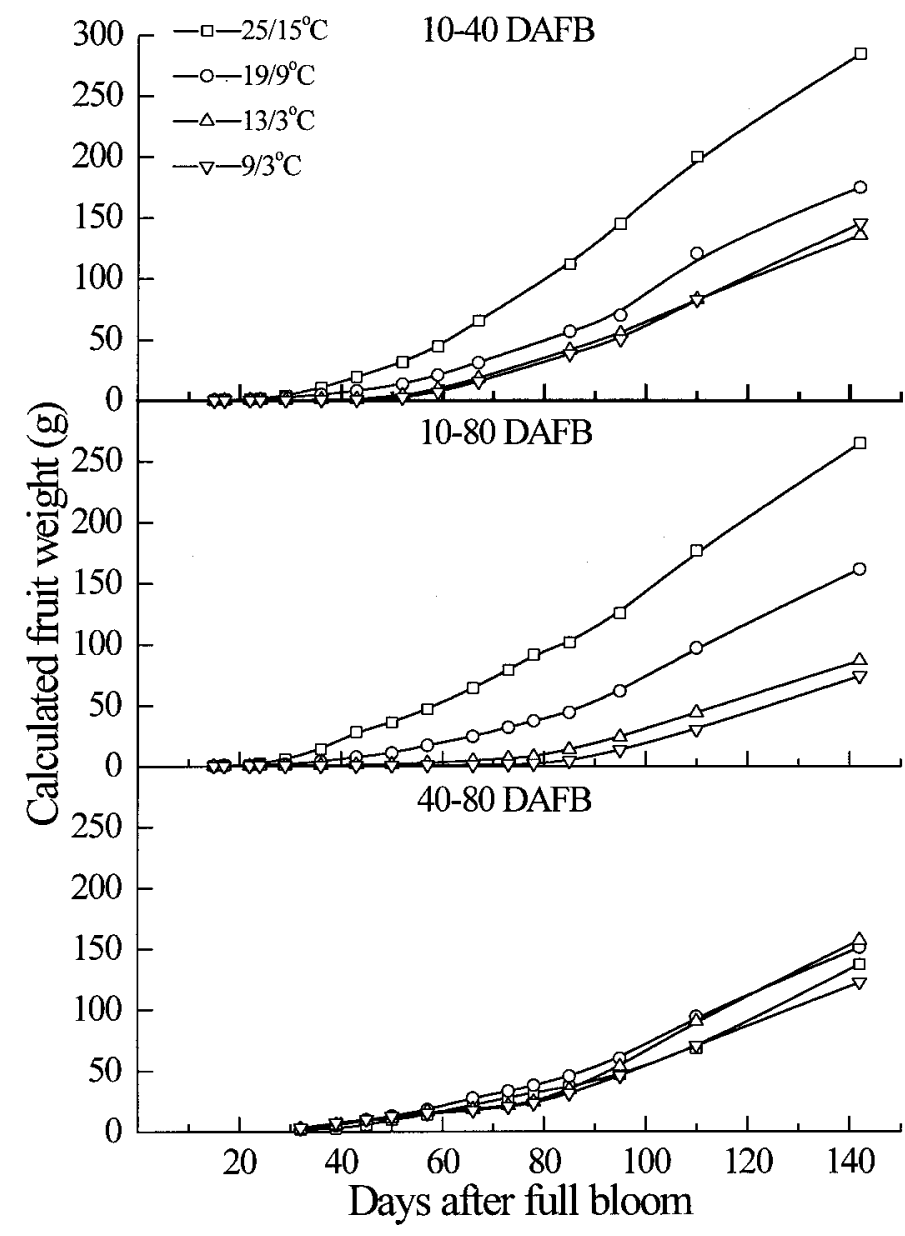

Fig. 1. Calculated mean fruit weight (g) over time for 'Delicious' subjected to four different temperature regimes at three growth phases under controlled environment conditions (1994-95). Diameters were converted to weights using an equation developed for 'Royal Gala' (de Silva et al., 1997). 


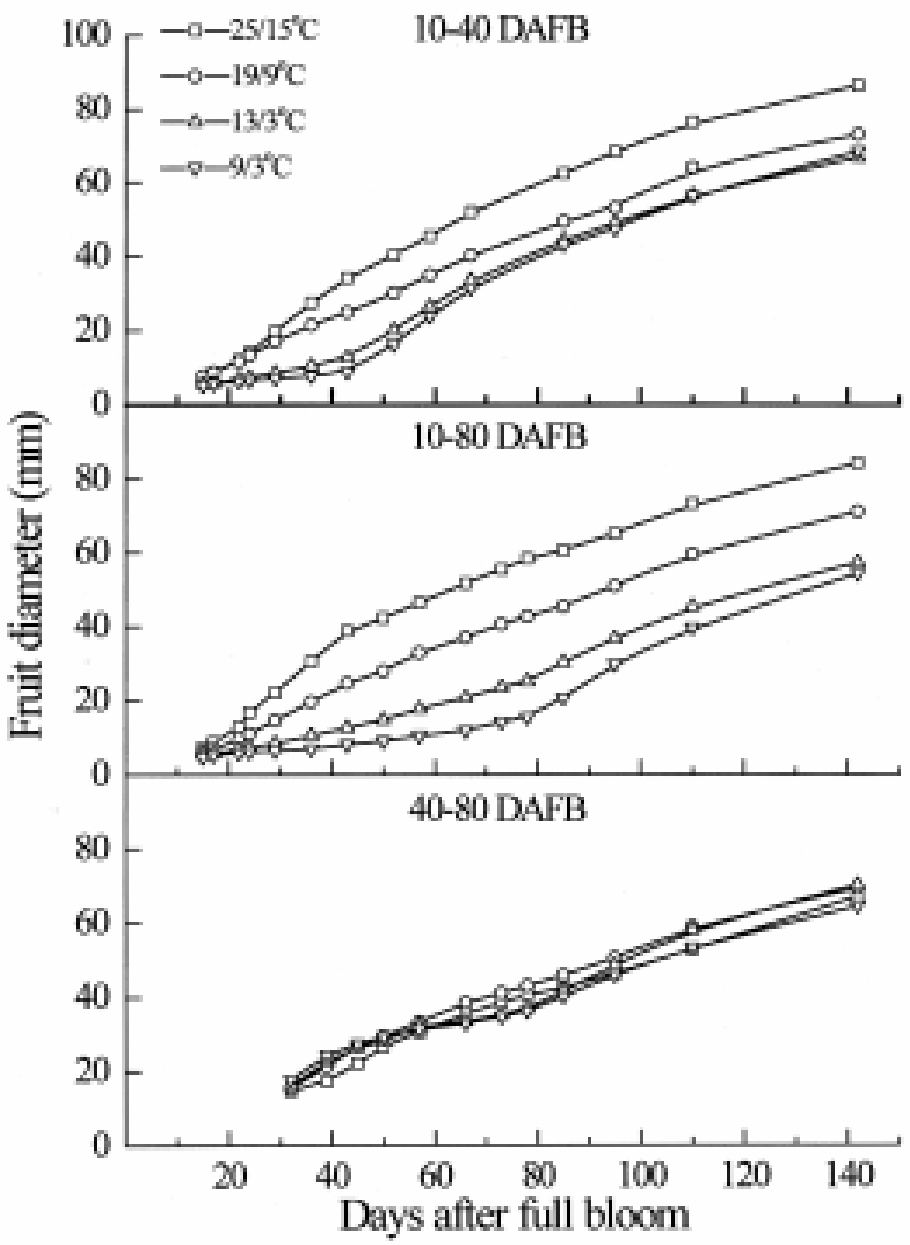

Fig. 2. Meanfruit diameterovertime for 'Delicious' subjected to fourtemperature regimes at three growth phases under controlled environment conditions (1994-95).

Mean fruit weight at harvest was not significantly affected by temperature imposed over the 40 to $80 \mathrm{DAFB}$ period for either cultivar (Table 3).

Temperature effects were even greater for fruit exposed to temperature treatments for a longer period, i.e., 10 to 80 DAFB. Volumetric growth rates calculated from Table 2 indicate that for 'Delicious', at 60 DAFB, fruit subjected to the $25 / 15^{\circ} \mathrm{C}$ treatment were growing $\approx 80$ times faster than fruit at $13 / 3{ }^{\circ} \mathrm{C}$ (Figs. 1 and 2 ). The effect on 'Braeburn' was less pronounced.

EXPERIMENT 3. The 1995-96 treatments included two mean temperatures $\left(11\right.$ and $\left.17{ }^{\circ} \mathrm{C}\right)$, each at two maximum/minimum temperature differentials $\left(10\right.$ and $\left.16^{\circ} \mathrm{C}\right)$. Only 'Braeburn', was tested. For trees grown in the $16 / 6,19 / 3,22 / 12$, and $25 / 9{ }^{\circ} \mathrm{C}$ temperature regimes, mean fruit expansion rates from 10 to 40 DAFB were $0.60,0.65,1.04$, and $1.14 \mathrm{~mm} \cdot \mathrm{d}^{-1}$, respectively, with a SE ratio of 1.07 . Clearly there was no statistical evidence that maximum/minimum temperature differential significantly affected fruit expansion rate, although there was a tendency for the wider maximum/minimum temperature differential to give a greater fruit expansion rate. Mean fruit expansion rate at a mean temperature of $17^{\circ} \mathrm{C}$ was, on average, 1.75 times greater than that at $11^{\circ} \mathrm{C}$.

EXPERIMENT 4. Temperatures imposed from 1 to 40 DAFB significantly affected mean fruit expansion rate measured from 10 to 40 DAFB. Rates at $22 / 12{ }^{\circ} \mathrm{C}$ were four times greater than those at $13 / 3{ }^{\circ} \mathrm{C}$ for both 'Braeburn' and 'Fuji' (Table 4). With both cultivars, the magnitude of these differences in mean fruit expansion rates, however, was not reflected in the final harvest fruit weight (Table 4). Clearly, after the trees were transferred to warmer outdoor temperatures at $40 \mathrm{DAFB}$, fruit that were previously subjected to a lower temperature treatment grew at a significantly faster average growth rate than those that had been exposed to the higher temperature. This trend for 'Fuji' is similar to that seen in the 1993-94 experiment but the longer exposure to the $13 / 3^{\circ} \mathrm{C}$ regime in 1996 97 led to a lower overall fruit expansion rate. Similarly for 'Braeburn' the results generally agree with that of 1994-95 experiment. The mean fruit expansion rates measured for 'Royal Gala' at $13 / 3{ }^{\circ} \mathrm{C}$ were similar to those for 'Fuji' but final harvest fruit weight was much smaller. Fruit abortion on 'Royal Gala' trees occurred extensively while trees were in the $22 / 12^{\circ} \mathrm{C}$ temperature treatment so data are unavailable for that treatment combination. No obvious cause of that fruit loss was apparent.

Estimates of fruit expansion rates from 10 to 40 DAFB, obtained from all four experiments show that, for all four cultivars, linear regressions of fruit expansion rate against the mean daily temperature were significant $(P \leq 0.01)$ (Fig. 3). Within the range of mean temperatures shown $\left(6\right.$ to $\left.20^{\circ} \mathrm{C}\right)$, the average fruit expansion rate from 10 to 40 DAFB increased by 0.062 to $0.075 \mathrm{~mm} \cdot \mathrm{d}^{-1}$ for each degree increment in temperature.

TEMPERATURE EFFECTS ON HARVEST FRUIT QUALITY. Each cultivar was harvested when fruit within any one of the treatments reached

Table 4. Mean expansion rates between 10 to $40 \mathrm{~d}$ after full bloom (DAFB), and mean harvest weight of fruit on trees subjected to four controlled temperature regimes from 1 to 40 DAFB. [Expt. 4 (1996-97)].

\begin{tabular}{|c|c|c|c|c|c|}
\hline \multirow[b]{3}{*}{ Cultivar } & \multicolumn{4}{|c|}{ Max/min temp $\left({ }^{\circ} \mathrm{C}\right)$} & \multirow{3}{*}{$\begin{array}{c}\text { SE } \\
\text { ratio }^{z}\end{array}$} \\
\hline & $13 / 3$ & $13 / 3$ & $22 / 12$ & $22 / 12$ & \\
\hline & Room A & Room B & Room C & Room D & \\
\hline & \multicolumn{5}{|c|}{ Fruit expansion rate $\left(\mathrm{mm} \cdot \mathrm{d}^{-1}\right)$} \\
\hline 'Braeburn' & $0.22 b^{y}$ & $0.21 \mathrm{~b}$ & $0.96 \mathrm{a}$ & $0.95 \mathrm{a}$ & $1.03^{* * * *}$ \\
\hline 'Fuji’' & $0.15 \mathrm{c}$ & $0.18 \mathrm{~b}$ & $0.78 \mathrm{a}$ & $0.81 \mathrm{a}$ & $1.04^{* * * *}$ \\
\hline \multirow[t]{2}{*}{ 'Royal Gala' } & $0.18 \mathrm{a}$ & $0.19 \mathrm{a}$ & --- & --- & $1.05^{* * *}$ \\
\hline & \multicolumn{4}{|c|}{ Harvest fruit wt $(\mathrm{g})^{\mathrm{x}}$} & $\operatorname{LSD}_{(0.05)}$ \\
\hline 'Braeburn' & $175 \mathrm{~b}$ & $190 \mathrm{ab}$ & $196 \mathrm{a}$ & $198 \mathrm{a}$ & $16^{(*)}$ \\
\hline 'Fuji' & 165 & 166 & 185 & 180 & $31^{\mathrm{NS}}$ \\
\hline 'Royal Gala' & 113 & 109 & --- & --- & $15^{\mathrm{Ns}}$ \\
\hline
\end{tabular}

${ }_{\mathrm{z}}$ Multiply or divide the estimate of expansion rate by the SE ratio to obtain the lower and upper bounds of unit standard error about the mean.

${ }^{y}$ Mean separation within rows by Fisher's protected LSD, $P \leq 0.05$.

${ }^{x}$ All fruit harvested when those at $22 / 12^{\circ} \mathrm{C}$ had reached commercial harvest maturity.

Ns, $(*),{ }^{* * *}$ Nonsignificant or significant at $P \leq 0.10$, or 0.001 , respectively. 


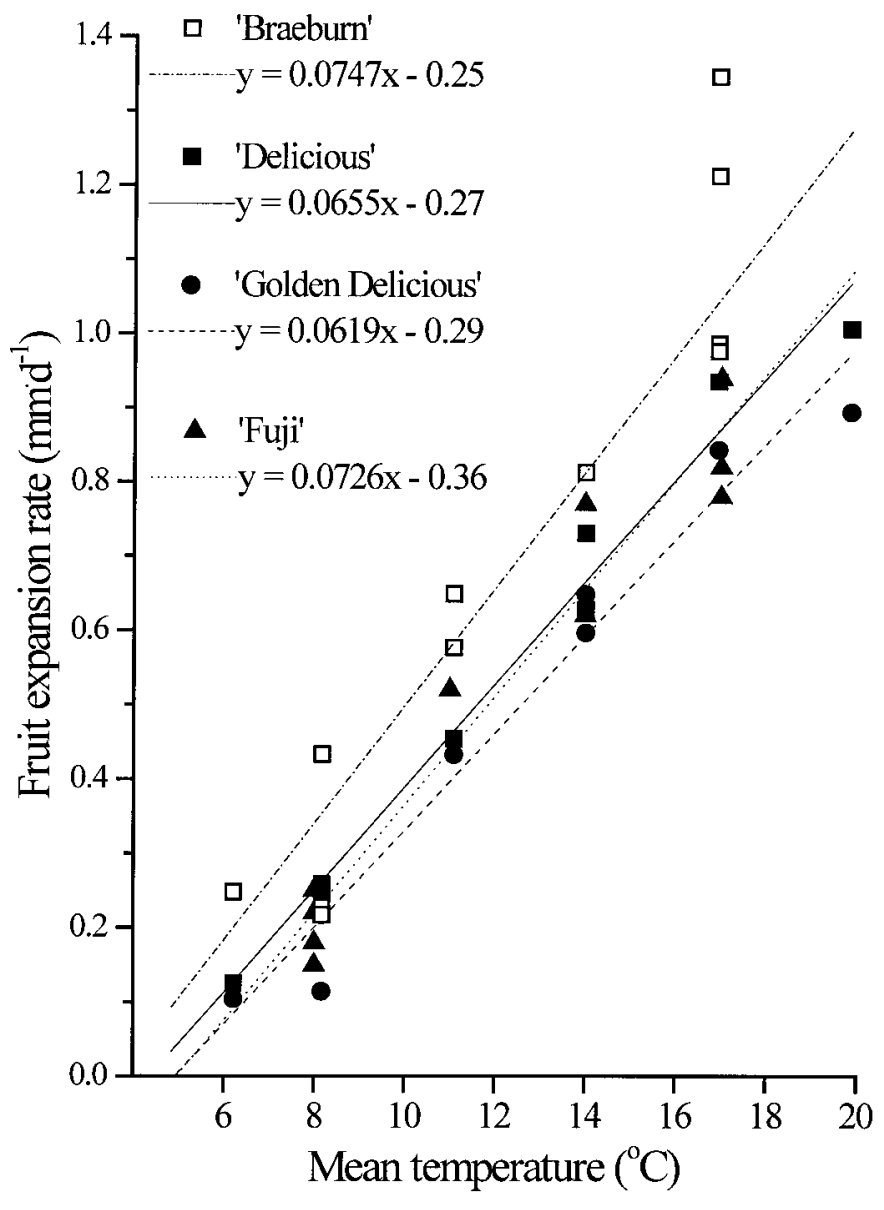

Fig. 3. Mean fruit expansion rate from 10-40 DAFB, for four apple cultivars, plotted against mean of the maximum/minimum temperature regime imposed in the same period under controlled environment conditions in three studies from 1993-94 through 1996-97. a stage of maturity similar to that used in commercial practice. Generally, fruit to fruit variability was high for maturity traits, and this, together with small sample sizes, meant that differences among treatment means were not always statistically significant.

In the 1993-94 treatments, neither the SSC nor the starch pattern index differed significantly among the temperature treatments for 'Delicious', 'Golden Delicious' or 'Fuji'. There was some indication of a trend for 'Delicious', where SSC varied from 11.7\%, $12.5 \%, 12.9 \%$, to $13.1 \%$ for fruit previously subjected from 10 to 40 DAFB to $13 / 3,16 / 6,19 / 9$, and $22 / 12^{\circ} \mathrm{C}$, respectively. A significant $(P \leq 0.05)$ and systematic change in flesh firmness, which ranged from $99.9,97.5,87.8$ to $87.8 \mathrm{~N}$ was also evident for the same order of temperatures. 'Fuji', an inherently sweeter fruit had SSCs of $14.1 \%, 14.1 \%, 14.3 \%$, and $15.2 \%(P \leq 0.05)$ and fruit firmness pressures of $86.8,86.1,81.2$, and $73.7 \mathrm{~N}(P \leq 0.05)$, respectively. Differences among temperatures treatments for 'Golden Delicious' were not significant. No significant differences among temperatures were detected for fruit shape, starch pattern index or seed number for any of these cultivars.

In the 1994-95 treatments, significant trends were evident with 'Braeburn' for harvest SSC, flesh firmness, background color index, and starch pattern index values in response to temperature imposed from both 10 to 40 and 10 to 80 DAFB (Table 5). The SSC, starch pattern index, and background color increased progressively as temperature increased, while flesh firmness decreased. Differences in mean fruit background color were, however, quite small. These results indicate that fruit subjected to a higher temperature early in the growth phase reached physiological maturity faster than those given a lower temperature over the same period. The effects on maturity attributes when temperatures were imposed from 40 to 80DAFB were smaller, with a significant effect apparent only at the highest temperature. Compared with 'Braeburn', the temperature effects on fruit maturity indices for 'Delicious' were generally less pronounced (Table 5). Both the flesh firmness and starch pattern index, but not SSC, showed significant trends for the 10 to 40 and

Table 5. Estimates of mean fruit harvest indices for two apple cultivars exposed to different maximum/minimum temperatures at three growth stages under controlled environment conditions. [Expt. 2 (1994-95)].

\begin{tabular}{|c|c|c|c|c|c|c|c|c|c|c|}
\hline \multirow{3}{*}{$\begin{array}{l}\text { Period } \\
\left(\mathrm{DAFB}^{\mathrm{z}}\right)\end{array}$} & \multicolumn{5}{|c|}{ 'Delicious' } & \multicolumn{5}{|c|}{ 'Braeburn' } \\
\hline & \multicolumn{4}{|c|}{$\operatorname{Max} / \min$ temp $\left({ }^{\circ} \mathrm{C}\right)$} & \multirow[b]{2}{*}{$\operatorname{LSD}_{(0.05)}$} & \multicolumn{4}{|c|}{$\operatorname{Max} / \min$ temp $\left({ }^{\circ} \mathrm{C}\right)$} & \multirow[b]{2}{*}{$\operatorname{LSD}_{(0.05)}$} \\
\hline & $9 / 3$ & $13 / 3$ & $19 / 9$ & $25 / 15$ & & $9 / 3$ & $13 / 3$ & $19 / 9$ & $25 / 15$ & \\
\hline & \multicolumn{10}{|c|}{ Soluble solids concn (\%) } \\
\hline $10-40$ & $11.7 b^{y}$ & $11.8 \mathrm{~b}$ & $13.2 \mathrm{ab}$ & $14.5 \mathrm{a}$ & $2.5^{(*)}$ & $10.6 \mathrm{c}$ & $11.3 \mathrm{bc}$ & $12.0 \mathrm{ab}$ & $12.8 \mathrm{a}$ & $1.1^{*}$ \\
\hline $10-80$ & 12.6 & 11.4 & 12.5 & 13.8 & $3.5^{\mathrm{NS}}$ & $10.2 \mathrm{c}$ & $10.1 \mathrm{c}$ & $11.6 \mathrm{~b}$ & $13.3 \mathrm{a}$ & $1.0^{* * * *}$ \\
\hline $40-80$ & 11.7 & 11.5 & 12.4 & 12.4 & $2.1^{\mathrm{NS}}$ & $10.3 \mathrm{~b}$ & $10.8 \mathrm{~b}$ & $10.7 \mathrm{~b}$ & $12.3 \mathrm{a}$ & $1.0^{* * *}$ \\
\hline & \multicolumn{10}{|c|}{ Flesh firmness $(\mathrm{N})$} \\
\hline $10-40$ & $82 \mathrm{~b}$ & $88 \mathrm{a}$ & $80 \mathrm{~b}$ & $70 \mathrm{c}$ & $5^{* * * *}$ & $109 \mathrm{a}$ & $105 \mathrm{ab}$ & $99 \mathrm{~b}$ & $89 \mathrm{c}$ & $9^{* *}$ \\
\hline $10-80$ & $115 \mathrm{a}$ & $106 \mathrm{~b}$ & $81 \mathrm{c}$ & $67 \mathrm{~d}$ & $3^{* * * *}$ & $127^{\mathrm{x}} \mathrm{a}$ & $113 \mathrm{~b}$ & $95 \mathrm{c}$ & $89 \mathrm{c}$ & $7^{* * * *}$ \\
\hline $40-80$ & $88 \mathrm{a}$ & $85 \mathrm{a}$ & $84 \mathrm{ab}$ & $76 \mathrm{~b}$ & $8^{*}$ & 105 & 99 & 96 & 92 & $10^{\mathrm{NS}}$ \\
\hline & \multicolumn{10}{|c|}{ Starch pattern index } \\
\hline $10-40$ & $0.3 \mathrm{c}$ & $1.1 \mathrm{bc}$ & $1.4 \mathrm{ab}$ & $3.7 \mathrm{a}$ & $1.1^{* * * * *}$ & $0.9 \mathrm{~b}$ & $1.7 \mathrm{a}$ & $2.1 \mathrm{a}$ & $2.2 \mathrm{a}$ & $0.9^{* * *}$ \\
\hline $10-80$ & $0.1 \mathrm{c}$ & $0.2 \mathrm{c}$ & $1.6 \mathrm{~b}$ & $2.7 \mathrm{a}$ & $0.3^{* * * *}$ & $0.8 \mathrm{c}$ & $0.9 \mathrm{c}$ & $1.7 \mathrm{~b}$ & $3.7 \mathrm{a}$ & $0.6^{* * * *}$ \\
\hline $40-80$ & 0.7 & 0.8 & 1.0 & 1.2 & $0.9^{\mathrm{NS}}$ & 0.6 & 0.7 & 0.7 & 1.3 & $0.6^{\mathrm{NS}}$ \\
\hline & \multicolumn{10}{|c|}{ Background color index } \\
\hline $10-40$ & $2.6 \mathrm{c}$ & $2.1 \mathrm{c}$ & $4.5 \mathrm{~b}$ & $5.9 \mathrm{a}$ & $1.2^{* * * *}$ & $3.9 \mathrm{~b}$ & $3.9 \mathrm{~b}$ & $3.7 \mathrm{~b}$ & $4.3 \mathrm{a}$ & $0.4^{*}$ \\
\hline $10-80$ & $1.0 \mathrm{c}$ & $1.1 \mathrm{c}$ & $2.4 \mathrm{~b}$ & $6.0 \mathrm{a}$ & $1.1^{* * * *}$ & $3.4 \mathrm{~b}$ & $3.5 \mathrm{~b}$ & $3.6 \mathrm{~b}$ & $4.1 \mathrm{a}$ & $0.5^{* *}$ \\
\hline $40-80$ & $1.5 \mathrm{~b}$ & $2.1 \mathrm{~b}$ & $3.8 \mathrm{a}$ & $4.6 \mathrm{a}$ & $1.5^{* *}$ & $3.5 \mathrm{~b}$ & $3.9 \mathrm{a}$ & $3.7 \mathrm{ab}$ & $3.6 \mathrm{~b}$ & $0.2^{* *}$ \\
\hline
\end{tabular}

${ }^{\mathrm{z}} \mathrm{DAFB}=$ days after full bloom.

'Mean separation within rows by Fisher's protected LSD, $P \leq 0.05$.

${ }^{x}$ Mean is underestimated due to individual values frequently exceeding the upper limit of the penetrometer measurement.

ss, $(*), * * *, * * * *$ Nonsignificant or significant at $P \leq 0.10,0.05,0.01$, or 0.001 , respectively. 
Table 6. Estimates of mean fruit harvest indices for two apple cultivars exposed to different maximum/minimum temperatures from 1 to 40 DAFB under controlled environment conditions. [Expt. 4 (1996-97)].

\begin{tabular}{|c|c|c|c|c|c|c|}
\hline & \multicolumn{3}{|c|}{ 'Braeburn' } & \multicolumn{3}{|c|}{ 'Fuji' } \\
\hline & \multicolumn{2}{|c|}{$\operatorname{Max} / \min$ temp $\left({ }^{\circ} \mathrm{C}\right)$} & \multirow[b]{2}{*}{$\operatorname{LSD}_{(0.05)}$} & \multicolumn{2}{|c|}{$\operatorname{Max} / \min$ temp $\left({ }^{\circ} \mathrm{C}\right)$} & \multirow[b]{2}{*}{$\operatorname{LSD}_{(0.05)}$} \\
\hline & $13 / 3$ & $22 / 12$ & & $13 / 3$ & $22 / 12$ & \\
\hline Soluble solids (\%) & $10.4 b^{2}$ & $12.0 \mathrm{a}$ & $0.4^{* * *}$ & $13.5 \mathrm{~b}$ & $15.6 \mathrm{a}$ & $0.5^{* * * *}$ \\
\hline Flesh firmness $(\mathrm{N})$ & $73.6 \mathrm{a}$ & $58.9 \mathrm{~b}$ & $5.9^{* * * *}$ & $50.0 \mathrm{a}$ & $39.2 \mathrm{~b}$ & $3.9^{* * * *}$ \\
\hline Starch pattern index & $0.3 \mathrm{~b}$ & $2.2 \mathrm{a}$ & $0.4^{* * *}$ & $0.9 \mathrm{~b}$ & $4.6 \mathrm{a}$ & $0.9^{* * * *}$ \\
\hline Background color & $4.4 \mathrm{~b}$ & $5.8 \mathrm{a}$ & $0.5^{* * *}$ & $2.3 \mathrm{~b}$ & $5.8 \mathrm{a}$ & $0.6^{* * *}$ \\
\hline
\end{tabular}

${ }^{\mathrm{z}}$ Mean separation within rows by Fisher's protected LSD, $P \leq 0.05$.

${ }^{* * *}$ Significant at $P \leq 0.001$.

10 to 80 DAFB periods. With 'Delicious', mean background color was markedly affected by temperature within each timing treatment and was affected to a greater extent than occurred with 'Braeburn'.

Fruit harvest indices recorded in 1996-97 (Table 6) were significantly affected by temperatures previously imposed from 1 to 40 DAFB. For 'Braeburn' there was consistency in the results from both the 1994-95 and 1996-97 treatments, with lower temperature imposed early in the fruit growth phase causing a delay in maturation as indicated by lower SSC, starch pattern index and background color values, and higher fruit firmness. Results for 'Fuji' were similar, but more definite than those obtained in the 1993-94 experiment probably due to the greater replication used in 1996-97.

In the 1996-97 experiment, half the fruit were harvested at a single point in time when those in the $22 / 12^{\circ} \mathrm{C}$ conditions reached commercial harvest maturity, and the remainder to the same specified background color. When harvested to the same background color, final mean fruit weight of 'Braeburn', was larger for fruit subjected to the cooler temperature regime (221 g) compared with fruit from the warmer regime (198 g). There was a time difference of $\approx 1$ month between the first and final harvest, which meant that fruit subjected to low temperatures, and therefore maturing later, continued to grow under the prevailing outdoor conditions and produced larger fruit at final harvest (i.e., $221 \mathrm{~g}$ compared with $183 \mathrm{~g}$ ). In contrast, 'Fuji' which also had $\approx 1$ month between the first and last harvest, showed no significant difference in final mean fruit weight between the $13 / 3^{\circ} \mathrm{C}(179 \mathrm{~g})$ and $22 / 12{ }^{\circ} \mathrm{C}(183 \mathrm{~g})$ temperature treatments. Nonetheless, fruit from the $13 / 3{ }^{\circ} \mathrm{C}$ treatment had increased in weight from 165 to $179 \mathrm{~g}$ over this final month's development.

Of those traits measured at harvest, all were affected by temperature with one exception. Temperature effects on seed number were evident only at the lowest temperature $\left(9 / 3{ }^{\circ} \mathrm{C}\right.$, 1994-95 experiment), and where fruit were exposed for the longest duration (10 to 80 DAFB). With both 'Delicious' and 'Braeburn', mean seed number per fruit was 2.9 and 2.3 for this treatment, as compared with 5.4 and 7.9, respectively, for fruit exposed to $25 / 15^{\circ} \mathrm{C}$ over the same period. Prolonged exposure to low temperature conditions, therefore, resulted in abortion of about half the seeds in the fruit.

\section{Discussion}

FruIT Growth. The purpose of this study was to investigate and quantify the effect of early and midseason temperature on fruit growth of several apple cultivars. In field studies it had been observed that cooler spring periods in New Zealand's apple growing regions may lead to smaller fruit size. Previous studies of effects of temperature on fruit growth and maturation have been limited. Fruit growth and maturation are key processes that play a role in determining fruit size distribution at harvest and, while the two processes are physiologically interrelated, the impacts of temperature on each may be different. It is likely that maturation, and its associated biochemical processes, are influenced more directly by conditions near harvest than by conditions early in the season. In contrast, growth is likely to be strongly influenced by postbloom conditions early in the season during the period of maximum cell division.

Early studies on the morphology and cytology of developing apple fruit grown in field environments have established that cell division in both the pith and cortex is completed within 35 to $45 \mathrm{~d}$ after anthesis (Bain and Robertson, 1951; Tetley 1930, 1931; Tukey and Young, 1942). Divisions continue to a later stage in subepidermal cells and later still in epidermal cells to allow the epidermis to retain integrity while internal tissues continue to increase in size (Tetley, 1930). Following cessation of meristematic cell division, apple fruit growth is characterized firstly by vacuolation of cells, later by a rapid increase in the size of individual cells, and finally by rapid development of intercellular spaces. The predominance of cell division early in fruit development has led to the understanding that the diameter or weight of apples at $\approx 40$ to $50 \mathrm{~d}$ after bloom can be closely related to final fruit size (Batjer et al., 1960; Forshey, 1976). Furthermore, warm or high temperatures during this period of early development have generally been shown in field studies to significantly increase the rate of fruit growth, and vice versa with cooler temperatures (Bergh, 1990; Bergh and Cloete, 1992, Ford, 1979; Green, 1981; Kronenburg, 1988; Lakso et al., 1995; Peters, 1981; Seeley, 1981; Skene, 1980; Tukey, 1956; Welte, 1990; Westwood et al, 1967). It was these findings that led us to design the experiments in such a way as to investigate the temperature effects specifically at two main periods in the fruit growth cycle-before and after $40 \mathrm{~d}$ after full bloom. The hypothesis proposed was that the temperature had a larger effect in the first 40 DAFB during which cell division was predominant.

Results presented herein provide clear evidence that early fruit growth (up to 40 DAFB) was significantly affected by the growing temperature environment. There was at least an 8-fold increase in fruit mean diameter expansion rate (10 to 40 DAFB) between the $9 / 3$ and $25 / 15^{\circ} \mathrm{C}$ temperature regimes and each of the apple cultivars evaluated in this study showed the same general response to temperature over this development phase (Fig. 3). There were, nonetheless, distinct differences among cultivars in the magnitude of response.

Under the cooler temperatures $\left(9 / 3\right.$ and $\left.13 / 3{ }^{\circ} \mathrm{C}\right)$ there was marked increase in fruit expansion rate after the trees were transferred at 40 DAFB to a sheltered outdoor site. This response was consistent across the different experiments for each of the apple cultivars studied and appears to suggest that under such low temperature conditions, cell division is extended well beyond 40DAFB. 
Such an apparent extension of the cell division period has not been recorded in earlier field studies and yet it will need to be considered in approaches which attempt to model fruit growth under contrasting temperature histories.

Enhanced fruit growth following transfer from cooler, controlled environments to outdoor conditions may also have been due to improvement in carbohydrate production by trees under the substantially warmer field conditions. Temperature impacts on the carbon economy of the trees used in this study, however, would appear to have had little impact on fruit growth as marked differences in growth rates were not detected among temperature treatments imposed following completion of the main period of cell division-i.e., in the 40 to 80 DAFB treatments (Figs. 1 and 2).

Each of the cultivars evaluated in this study showed the same general response of fruit expansion rate to mean temperature. There were, nonetheless, apparent differences among cultivars in their actual expansion rates at any particular mean temperature (Fig. 3). Highest expansion rates were consistently determined for 'Braeburn' and lowest for 'Golden Delicious' with 'Fuji' and 'Delicious' being intermediate in their responses. The magnitude of the difference between 'Braeburn' and 'Golden Delicious' was between 0.15 and $0.25 \mathrm{~mm} \cdot \mathrm{d}^{-1}$.

The ability of 'Braeburn' to sustain reasonable growth rates at low temperatures is a possible explanation as to why this cultivar is able to produce fruit of adequate size when grown in cooler regions or in cooler seasons in contrast to cultivars such as 'Royal Gala' and 'Golden Delicious' where achieving adequate size under these conditions is a problem (Kronenberg, 1988).

Fruit expansion rate following the main phase of cell division was influenced to a lesser extent by temperature than it was during early fruit development. However, differences were still apparent as evident by differences in expansion rates among temperature treatments in the 40 to 80 DAFB treatments (Expt. 2).

Values presented in Tables 1 and 2 are for fruit expansion rate and consequently corresponding rates for periods following completion of different temperature treatments should not be used to compare growth directly. The reason for this constraint is that fruit are of different sizes at the end of the treatment periods and if two fruit are of different sizes but have the same mean fruit expansion rate, the larger fruit has a higher growth rate than the smaller one. If it is assumed that the surface area of a fruit $(\mathrm{A})$ is proportional to the squared value of a sphere of the same diameter $\left(A=k \times x^{2}\right)$, then the volumetric growth rate, $\mathrm{dv} / \mathrm{dt}$ can be expressed as: $\mathrm{dv} / \mathrm{dt}=\mathrm{k} \times \mathrm{x}^{2} \times$ $(\mathrm{dx} / \mathrm{dt})$. Therefore, at a given point in time the product of the squared value of the diameter ratio and the mean fruit expansion rate ratio, should provide an approximate value for the ratio of corresponding volumetric rates. Following such calculations it can be shown that fruit subjected to higher temperatures early in growth have greater volumetric growth rates in later periods, even when their mean fruit expansion rates are lower. For example, with 'Delicious', the estimated fruit volumetric growth rate outdoors at 60 DAFB (mid point in 40 to 80 DAFB range) of trees previously exposed to $25 / 15^{\circ} \mathrm{C}$ from 10 to $40 \mathrm{DAFB}$, was $\approx 3.5$ times that of fruit subjected to the $9 / 3{ }^{\circ} \mathrm{C}$ temperature treatment (Fig. 1). Therefore, even with the compensatory response of fruit grown previously at the lower temperatures, the trees subjected to higher temperatures from 10 to 40 DAFB can be expected to give relatively larger fruit weight at harvest. Consequently, for 'Delicious' there was a 2-fold increase of fruit weight at harvest in the $25 / 15^{\circ} \mathrm{C}$ treatment compared with the $9 / 3{ }^{\circ} \mathrm{C}$ treatment given at 10 to 40 DAFB (Table 3).

Fruit maturation. Fruit maturation is the result of a series of biochemical reactions occurring within the fruit which are manifested by changes in background color, firmness, soluble solids concentration, starch hydrolysis, acid content, and ethylene production. Those changes, that are readily measurable, are often used as indicators of maturity development. Commercially, apple crops are harvested based on a number of different maturity indices. With the exception of some correlative relationships, which have been established under field conditions, very few studies appear to have evaluated the direct impact of postbloom temperature on factors associated with maturation and ripening in apple.

The time that fruit reach optimum harvest maturity in commercial apple orchards can be influenced by a number of factors including bloom date and the environmental conditions, for example temperature, that prevail during fruit development. Some studies have determined a high correlation between accumulated heat units and the time interval between bloom and optimum harvest. For example, Eggert (1960) showed that the difference in heat units accumulated during the first $40 \mathrm{~d}$ following petal fall accounted for most of the variability found in the total elapsed time from petal fall to harvest with 'McIntosh'. Similarly, Blanpied and Ben-David (1970) found that variation during this development period could be accounted for best by day temperature during the first $30 \mathrm{~d}$ following bloom, and Kronenburg (1988) also found that the conditions prevailing during the first month after flowering had the greatest impact on harvest date. Some studies with pears (Pyrus communis L.) (Lombard et al., 1971) have shown similar correlations. Nonetheless, Abeles and Lightner (1984) using optimal harvest date equations, showed that bloom date was more important for determining the harvest date of six apple cultivars under conditions in West Virginia than mean temperatures during the growing season.

Tromp (1997), in a recent controlled environment study of the impacts of temperature on 'Elstar', found that both background color and firmness changed more slowly throughout fruit development following a 6-week postbloom exposure to $16 / 12^{\circ} \mathrm{C}$ compared with either $24 / 20$ or $20 / 16{ }^{\circ} \mathrm{C}$ conditions. Soluble solids concentration, however, was higher at $16 / 12{ }^{\circ} \mathrm{C}$ than at the two warmer conditions. Fruit weight at both $24 / 20$ and $20 / 16{ }^{\circ} \mathrm{C}$ remained constant from $\approx 105$ DAFB in his study and marked fruit drop occurred especially at higher temperatures which may have influenced the reported results. In a second study, the rates at which background color changed, flesh firmness decreased, starch degraded, and fruit reddening increased during growth were all higher when the temperature was maintained at $22 / 18^{\circ} \mathrm{C}$ for $72 \mathrm{DAFB}$ than when it was $16 / 12^{\circ} \mathrm{C}$. In that instance, differences in fruit weight between the two temperature regimes were negligible from 98 DAFB onwards and results for soluble solids concentration were inconclusive.

In our study, where fruit were harvested at a common time after full bloom, the soluble solids concentration was higher, the starch pattern index higher (i.e., starch concentration was lower), flesh firmness lower, and background color more yellow under warmer than under cooler maximum/minimum temperature conditions. Generally, these differences were similar among experiments, but some maturity indicators were less consistent in their response than others. SSC had a variable response, with no difference detected in some instances (at $P \leq 0.05$ ) even when all other indicators showed significant differences in maturity indices between treatment groups (Table 5). Overall, our results are in contrast with those obtained by Tromp (1997) as fruit in our study continued to expand until harvest and we determined an opposite response of soluble solids concen- 
tration to temperature. Early termination of fruit growth coupled with a more restricted root growth volume, low fruit numbers per tree, and a lower $P P F$ in the controlled temperature treatments, may have had an impact on the carbohydrate balance in the fruit used in Tromp's (1997) study and could account for these differences.

Our studies show the marked impact that temperatures in the 30 to $40 \mathrm{~d}$ interval following bloom can have on maturity indices at harvest which occurs some 90 to $140 \mathrm{~d}$ after the temperature treatments were terminated. These controlled environment results are in close agreement with correlative analyses of field observations which have shown that conditions in the period from 30 to 40 $\mathrm{d}$ after bloom are most critical in determining harvest maturity (Blanpied and Ben-David, 1970; Eggert, 1960; Kronenburg, 1988). In contrast, treatments imposed later than 40 DAFB have been shown to be largely ineffective. In our study, temperatures imposed 40 to 80 DAFB had virtually no impact, for example, on either flesh firmness or starch pattern index. Similarly, Blankenship (1987) determined no impact of two contrasting night temperatures imposed from 52 DAFB on fruit maturation measured either as soluble solids concentration or firmness.

Previous studies (Westwood et al., 1967) have shown that small fruit usually contain fewer and smaller cells than large fruit, and Bergh (1990) demonstrated that higher fruit growth rates under warm early season temperature conditions were associated with increased rates of cell division in the cortical region of fruit at this time. Considering these observations and the fact that cell division is completed early in fruit development, it is not surprising that fruit firmness at harvest, which is likely to be highly correlated with cell size and specific gravity (i.e., lower percentage air space; Westwood, 1962), is determined so early in development. This is confirmed by the fruit firmness data for both 'Delicious' and 'Braeburn' in 199495 where fruit were exposed to the different temperature regimes over three complimentary development phases. For those fruit subjected to the 40 to 80 DAFB treatment, which would have been after completion of the main phase of cell division, mean temperature in the field postbloom until $40 \mathrm{DAFB}$ was $\approx 14^{\circ} \mathrm{C}$ (i.e., the same as the $19 / 9{ }^{\circ} \mathrm{C}$ treatment). Differences in flesh firmness values among temperatures within the 40 to 80 DAFB treatment were much smaller that those in both the 10 to 40 and 10 to 80 DAFB treatments and, on average, were similar to those from the $19 / 9^{\circ} \mathrm{C}$ 10 to 40 DAFB treatment (Table 5).

The conclusions, that cell size and number were directly influencing fruit firmness are consistent with the observation that increased cell division, stimulated by application of benzyladenine, resulted in enhanced firmness in treated compared with nontreated apple fruit even though fruit were larger (Wismer et al., 1995). It is not so apparent, however, as to why other maturity indices, such as soluble solids concentration, starch pattern index or background color, should be influenced by temperature conditions in the period immediately following bloom.

REPLiCATION. In most research involving controlled environment chambers there is little or no true replication to test for between-chamber effects. In this study, some between-year replication was achieved within the design where specific temperature and duration treatments on the same cultivar were repeated in time.

Further, in the 1996-97 experiment, trees within each temperature regime were split equally between two controlled environment chambers to directly measure any potential chamber effects. In this instance, only the between-chamber differences for fruit expansion rates of 'Fuji' were statistically significant.

The results overall provide little evidence to indicate that chambers had a significant effect on plant response. Previous experience in this facility, where the chambers are of identical design and the environmental factors are continuously monitored, has also indicated that between-chamber effects are negligible (e.g., Warrington and Kanemasu, 1983).

MODEL DEVELOPMENT. The temperature dependent relationships determined in this study have provided the basic inputs required for development of a model to predict potential size from early season temperatures and actual growth rates during the development of apples (Austin et al., 1998).

\section{Literature Cited}

Abbott, D.L. and V. Bull. 1973. Physiology of the apple tree. Rpt. Long Ashton Res. Sta. (1972), p. 33-36.

Abeles, F.B. and G.W. Lightner. 1984. Optimal harvest date equations for West Virginia apples. HortScience 19:429-430.

Austin, P.T., A.J.Hall, P.W. Gandar, I.J. Warrington, T.A. Fulton, and E.A. Halligan. 1999. A compartment model of the effect of early-season temperatures on potential size and growth of 'Delicious' apple fruits. Ann. Bot. 83:129-143.

Bain, J.M. and R.N. Robertson. 1951. The physiology of growth of apple fruits. I. Cell size, cell number, and fruit development. Austral. J. Biol. Sci. 4:75-91.

Batjer, L.P., H.D. Billingsley, M.N. Westwood, and B.L. Rogers. 1960. Predicting harvest size of apples at different times during the growing season. Proc. Amer. Soc. Hort. Sci. 70:46-57.

Beattie, B.B. and R.R.W. Folley. 1978. Production variability in apple crops. II. The long term behavior of English crops. Scientia Hort. 8:325332.

Bergh, O. 1990. Effect of temperature during the first 42 days following full bloom on apple fruit growth and size at harvest. S. Afr. J. Plant Soil. 7:1118.

Bergh, O. and de V. Cloete. 1992. Effect of different day and night temperatures on the diurnal growth rate of terminal and lateral fruits in Golden Delicious apple. S. Afr. J. Plant Soil 9:68-72.

Blankenship, S.M. 1987. Night-temperature effects on rate of apple fruit maturation and fruit quality. Scientia Hort. 33:205-212.

Blanpied, G.D. and S. Ben-David. 1970. A New York study of 'McIntosh' apple optimum harvest dates. J. Amer. Soc. Hort. Sci. 95:151-154.

Blanpied, G.D. and N.D. O'Kennedy. 1967. A study of the relationships between climate and apple fruit growth. HortScience 2:155-156.

Blanpied, G.D. and M.H. Wilde. 1968. A study of the cells in the outer flesh of developing McIntosh apple fruits. Bot. Gaz. 129:178-183.

Bollard, E.G. 1970. The physiology and nutrition of developing fruits, p. 387-485. In: A.C. Hulme (ed.). The biochemistry of fruits and their products. vol. 1. Academic Press, London.

Brooking, I.R. 1976. Soilless potting media for controlled environment facilities. N.Z. J. Expt. Agr. 4:203-208.

de Silva, H.N., D.S. Tustin, W.M. Cashmore, C.J. Stanley, G. Lupton, and S.J. McArtney. 1997. The fruit fresh weight-diameter relationship for 'Royal Gala' apple across seasons and among fruit production regions of New Zealand. HortScience 32:1169-1173.

DSIR., 1981. The DSIR climate laboratory. Alpha No. 14. Department of Scientific and Industrial Research (DSIR) Ext. Info., Wellington, N.Z.

Eggert, F.G. 1960. The relation between heat unit accumulation and length of time required to mature McIntosh apples in Maine. Proc. Amer. Soc. Hort. Sci. 76:98-105.

Ford, E.M. 1979. Effect of post-blossom environmental conditions of fruit composition and quality of apple. Commun. Soil Sci. Plant Anal. 10:337348.

Forshey, C.G. 1976. McIntosh apple crop prediction studies. Proc. 82nd. Annu. Mtg. Mass. State Hort. Soc. 82:86-89.

Gandar, P.W., A.J. Hall, and H.N. de Silva. 1996. Deterministic models for fruit growth. Acta Hort. 416:103-112.

Green, L. 1981. Temperature and Red Delicious apple size. Proc. 77th Annu. Mtg. Wash. State Hort. Soc. p. 36-38.

Jackson, J.E. and P.J.C. Hamer. 1980. The causes of year-to-year variation 
in the average yield of Cox's Orange Pippin apple in England. J. Hort. Sci. 55:149-156.

Jackson, J.E., P.J.C Hamer, and M.F. Wickenden. 1983. Effects of early spring temperatures on the set of fruits of Cox's Orange Pippin apple and year-to-year variation in its yields. Acta Hort. 139:75-82.

Kronenberg, H.G. 1988. Temperature requirements for growth and ripening of apples. Neth. J. Agr. Sci. 36:23-33.

Lakso, A.N., L. Corelli Grappadelli, J. Barnard, and M.C. Goffinet. 1995. An expolinear model of the growth pattern of the apple fruit. J. Hort. Sci. 70:389-394.

Lombard, P.B., C.D. Cordy, and E. Hansen. 1971. Relation of postbloom temperatures to 'Bartlett' pear maturation. J. Amer. Soc. Hort. Sci. 96:799-801.

Peters, C. 1981. Factors affecting pollination, fruit set, size and shape of Red Delicious apples. Proc. 77th. Annu. Mtg. Wash. State Hort. Soc. p. 43-46.

Pratt, C.S. 1988. Apple flower and fruit: Morphology and anatomy. Hort. Rev. 10:273-308.

Schechter, I., J.T.A. Proctor, and D.C. Elfving. 1993a. Characterization of seasonal fruit growth of 'Idared' apple. Scientia Hort. 54:203-210.

Schechter, I., J.T.A. Proctor, and D.C. Elfving. 1993b. Reappraisal of seasonal apple fruit growth. Can. J. Plant Sci. 73:549-556.

Seeley, E. J. 1981. Physiological factors affecting fruit size and quality. Proc. 77th. Annu. Mtg. Wash. State Hort. Soc. p. 38-42

Skene, D.S. 1980. Growth stresses during fruit development in Cox's Orange Pippin apples. J. Hort. Sci. 55:27-32.

Tetley, U. 1930. A study of the anatomical development of the apple and some observations on the "pectic constituents" of the cell walls. J.
Pomol. 8:153-172.

Tetley, U. 1931. The morphology and cytology of the apple fruit, with special reference to the Bramley's seedling variety. J. Pomol. 9:278297.

Tromp, J. 1997. Maturity of apple cv. Elstar as affected by temperature during a six-week period following bloom. J. Hort. Sci. 72:811-819.

Tukey, H.B. and J. Oran Young. 1942. Gross morphology and histology of developing fruit of the apple. Bot. Gaz. 104:3-25.

Tukey, L.D. 1956. Some effects of night temperature on the growth of McIntosh apples. I. Proc. Amer. Soc. Hort. Sci. 68:32-43.

Tukey, L.D. 1959. Some effects of night temperature on the growth of McIntosh apples. II. Proc. Amer. Soc. Hort. Sci. 75:39-46.

Warrington, I.J., T. Dixon, R.W. Robotham, and D.A. Rook. 1978. Lighting systems in major New Zealand controlled environment facilities. J. Agr. Eng. Res. 23:23-36.

Warrington, I.J. and E.T. Kanemasu. 1983. Corn growth response to temperature and photoperiod. I. Seedling emergence, tassel initiation and anthesis. Agron. J. 75:749-754.

Welte, H.F. 1990. Forecasting harvest fruit size during the growing season. Acta Hort. 276:275-282.

Westwood, M.N. 1962. Seasonal changes in specific gravity and shape of apple, pear, and peach fruits. Proc. Amer. Soc. Hort. Sci. 80:90-96.

Westwood, M.N., L.P. Batjer, and H.D. Billingsley. 1967. Cell size, cell number and fruit density of apples as related to fruit size, position in the cluster and thinning method. J. Amer. Soc. Hort. Sci. 91:51-62.

Wismer, P.T., J.T.A. Proctor, and D.C. Elfving. 1995. Benzyladenine affects cell division and cell size during apple fruit thinning. J. Amer. Soc. Hort. Sci. 120:802-807. 